\title{
Comparative effectiveness, growth and dispersal of stocked Arctic char (Salvelinus alpinus) from different origins in Lake Annecy
}

\author{
M.Y. Janjua(1), D. Zanella(1), D. Gerdeaux ${ }^{(1)}$
}

Received April 29, 2010 / Reçu le 29 avril 2010

Revised June 18, 2010 / Révisé le 18 juin 2010

Accepted June 18, 2010 / Accepté le 18 juin 2010

Key-words: Arctic char, growth, stocking, dispersal, Lake Annecy

\section{ABSTRACT}

The fisheries managers of the Lake Annecy stocked Arctic char Salvelinus alpinus fingerlings from different origins including progeny of wild brood fish from Lake Geneva, wild brood fish from Lake Annecy and captive brood stock from the INRA hatchery in Thonon to improve the catches. The effectiveness of stocking, growth and dispersal after release of Arctic char from these different origins were studied for the fish stocked in 1997. Another experiment was started in 2001, to confirm the previous results on effectiveness and growth. The growth of wild Arctic char was not very different from the hatchery-reared stock. The portion of natural breeding in the catches was $50 \%$. Juveniles produced from INRA captive brood stock were found to be more effective in the catch among the stocked fish and also showed wider dispersal after stocking. Mean effectiveness of the stocking was found to be $14 \%$.

\section{RÉSUMÉ}

Efficacité comparée, croissance et dispersion des alevins d'omble chevalier (Salvelinus alpinus) de différentes origines déversés dans le lac d'Annecy

Mots-clés : omble chevalier, croissance, alevinage, dispersion, lac d'Annecy
Les gestionnaires de la pêche au lac d'Annecy alevinent des juvéniles d'omble chevalier Salvelinus alpinus de différentes origines dont des descendants de géniteurs sauvages du lac Léman, du lac d'Annecy et d'un stock captif provenant de la pisciculture INRA de Thonon pour augmenter les captures. L'efficacité de l'alevinage, la croissance et la dispersion des ombles de ces différentes origines ont été étudiées pour l'alevinage de 1997. Une autre expérience a été réalisée en 2001. La croissance de l'omble issu de reproduction naturelle n'est pas différente de celle des alevins de pisciculture. Les ombles issus de la reproduction naturelle représentent $50 \%$ des captures. Les juvéniles issus du stock captif de l'INRA ont un taux de recapture plus fort que les autres juvéniles et montrent également une plus grande dispersion après alevinage. Le taux de recapture moyen est estimé à $14 \%$.

\section{INTRODUCTION}

The Arctic char Salvelinus alpinus (L.) is a northern, circumpolar salmonid with pronounced differences in morphological, life history and behavioural traits between populations (Johnson, 1980). It is very diverse in appearance, feeding habits and growth (Kahilainen and Lehtonen, 2002). Arctic char is popular among European anglers and is often stocked in Alpine lakes to supplement the natural reproduction.

(1) INRA Station d'hydrobiologie lacustre, BP 511, 74203 Thonon-les-Bains, France, janjua@thonon.inra.fr 
Release of hatchery-reared fish into natural ecosystems is widely practised for improvement and restoration of natural stocks. Hatchery-reared and wild fish can differ in many respects, e.g., their phenotype may be shaped considerably by the rearing environment (Wootton, 1994; Wessel et al., 2006), direction and intensity of selection may be different in two types of environment (Einum and Fleming, 2000), and use of non-native brood fish in the hatchery can have different results (Gharrett and Smoker, 1991). The biological effectiveness of stocking depends on both post-release performance of hatchery-reared fish and on the stocking and harvesting management (Lorenzen, 2005). To study the effectiveness of stocked fish in fisheries, it is necessary to measure their growth and dispersal after the stocking. Such parameters can be estimated by stocking experiments with marked fish.

The effectiveness of Arctic char stocking in Lake Geneva (Champigneulle and Gerdeaux, 1995) encouraged the Lake Annecy Anglers Association (ALP) to increase the Arctic char fingerling stocking in Lake Annecy from 50000 to 120000 in 1993. Traditionally the eggs were collected from the wild Arctic char in the spawning grounds during December each year. The increase in the stocking target incited the ALP to find fingerlings from other sources including; wild brood fish from Lake Geneva, wild brood fish from Lake Annecy and captive brood stock from the INRA experimental hatchery in Thonon-les-Bains. The effectiveness of stocking, the growth after release and dispersal of stocked Arctic char from these three different origins was tested in Sub-Alpine Lake Annecy in two long experiments started in 1997 and 2001 to choose the best stocking strategy. The results from the study can be used to define the better management of Arctic char stocking in Lake Annecy.

\section{MATERIAL AND METHODS}

\section{$>$ THE STUDY LAKE}

Lake Annecy, situated in the Rhône-Alpes region of France, $50 \mathrm{~km}$ south of Lake Geneva, is $14.6 \mathrm{~km}$ long and $0.8-3.2 \mathrm{~km}$ wide, with a total surface area of 2740 ha. At $447 \mathrm{~m}$ above sea level, the maximum depth of the lake is $65 \mathrm{~m}$ and the mean depth is $41.5 \mathrm{~m}$. The lake has steep banks and a relatively flat bottom, and is divided into a northern "large lake" and a southern "small lake". The surface temperatures rarely exceed $23{ }^{\circ} \mathrm{C}$ in the summer and are never below $4{ }^{\circ} \mathrm{C}$ in the winter. Lake Annecy is monomictic and never covered with ice. The water is well oxygenated throughout the year except at the depth of 60-65 m, which is deoxygenated each year in autumn. The lake was mesotrophic about 30 years ago and is oligotrophic now.

Natural barriers prevented whitefish and Arctic char from colonising Lake Annecy. They were introduced into the lake in the 1890s from native stocks in Lake Geneva and Bourget, both also situated in the Rhone basin (Le Roux, 1908, 1911). A hatchery is run by the Lake Annecy Angler Association (ALP) on the shore of the lake to rear Arctic char and brown trout fingerlings. Brown trout (Salmo trutta), Arctic char (Salvelinus alpinus) and whitefish (Coregonus lavaretus) compose more than $80 \%$ of the yield of the present fish community (Gerdeaux and Janjua, 2009). Pike (Esox lucius) and perch (Perca fluviatilis) are also caught and produce $10 \%$ of the yield. Burbot (Lota lota) and some cyprinids (roach (Rutilus rutilus), bream (Abramis brama), and carp (Cyprinus carpio)) make up the last $10 \%$. The introduced whitefish population maintains itself without stocking, whereas the Arctic char is stocked constantly because of the insufficient spawning sites (Gerdeaux et al., 1995).

\section{> MARKING AND STOCKING}

For the experiment, Lake Annecy was stocked with fingerlings (Table I) from captive brood stock of Lake Geneva origin (LGC), from wild Lake Annecy fish (LAW) and from wild Lake Geneva fish (LGW). The LGC and LAW fingerlings were reared at the Lake Annecy hatchery on commercial dry food plus bulk zooplankton from the lake, while the LGW batch was fed 


\section{Table I}

Numbers of stocked arctic char fingerlings from three different sources during 1997 and 2001 and their respective catches by volunteer anglers during the $2 n d$, 3rd and 4th years after stocking.

Tableau I

Nombre de juvéniles d'omble chevalier des différentes origines en 1997 et 2001 et leur recapture respective par les pêcheurs amateurs deux, trois et quatre années après alevinage.

\begin{tabular}{|l|c|c|c|c|c|c|}
\hline Stocking & Origin & Numbers & Year +2 & Year +3 & Year +4 & Total \\
\hline $\mathbf{1 9 9 7}$ & LAW & 18260 & 11 & 27 & 9 & 47 \\
& LGC & 51950 & 178 & 155 & 32 & 365 \\
& LGW & 40000 & 38 & 40 & 21 & 99 \\
\hline $\mathbf{2 0 0 1}$ & LAW & 15000 & 5 & 3 & 15 & 23 \\
& LGC & 48000 & 41 & 25 & 39 & 105 \\
& LGW & 40000 & 6 & 6 & 36 & 48 \\
\hline
\end{tabular}

only on dry food. Two stocking experiments were conducted. The first experiment was started in 1997, and the second experiment was started in 2001 on a smaller scale. The four-year gap between the two experiments ensured that the previously marked fish were almost all out of the fisheries.

In 1997 all LAW fish were marked by removing the adipose fin, all LGW fish by removing the left pelvic fin and all LGC fish by removing the right pelvic fin. In 2001, 103000 out of the 138000 stocked fish were marked, but this time, by removing the adipose fin (LGW), left pelvic fin (LGC) and right pelvic fin (LAW). After marking, fingerlings were checked in the hatchery for 4-5 days before stocking. Average length at stocking time was $7.1 \pm 1.3 \mathrm{~cm}$. In 1997, stocking was done between 16th and 25th July, while in 2001, it was done between 10th and 17th July. The fingerlings from the different origins were released into the lake at different sites around the lake (Figure 1).

\section{> DATA COLLECTION}

To reduce sampling costs, catch data were collected with the help of anglers. The obligatory daily catch data provided by anglers and commercial fishermen give a good estimation of the fish caught, but no information on marked fish. Since 1992, a group of about 20 volunteer anglers from the ALP at Lake Annecy has collaborated to provide the date, species, mark (if any), total length and the location for each fish they catch, including those which were released back (Gerdeaux and Janjua, 2009). They also collected scales from and recorded the weight of each fish above the minimal legal size $(26 \mathrm{~cm})$. The quality of marking and data collection was secured by two annual meetings with the volunteers during the eight years of this experiment. The monitoring of the stocking carried out in 2001 was not very intensive during the 2 nd and 3 rd years after stocking.

\section{> EFFECTIVENESS OF STOCKING}

The percentage of marked fish caught each year was determined from the volunteer catches and then these figures were extrapolated to the total number of Arctic char caught during the study period using the data for obligatory daily fisheries statistics of both recreational and commercial fisheries from the Department of Agriculture and Forest of Haute-Savoie (DDAF). The unmarked wild fish in catches were from different generations. The numbers of the 1997 wild generation in the catches were estimated by ageing the catch using scale readings for unmarked fish in 1997 and with an adjustment for the 2001 wild generation, taking into account that all the stocked fish were not marked in 2001. 


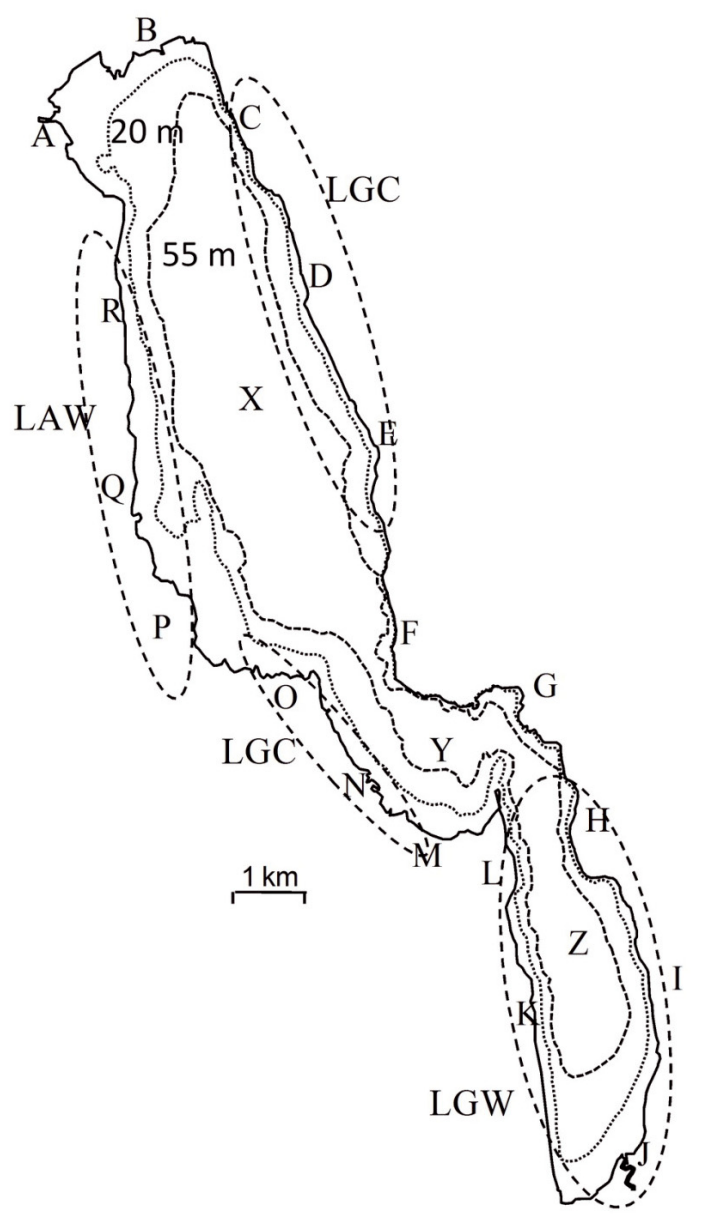

\section{Figure 1}

Map of Lake Annecy showing the bathymetric curves for $20 \mathrm{~m}$ and $55 \mathrm{~m}$. A-Z are the fish catch zones of anglers, while dotted ovals are the stocking zones of Arctic char fingerlings from different origins.

\section{Figure 1}

Carte du lac d'Annecy avec courbes bathymétriques de $20 \mathrm{~m}$ à $55 \mathrm{~m}$. A-Z sont les codes des zones de pêche, les ovales sont les zones d'alevinage des différentes origines.

\section{> BACK-CALCULATED LENGTH AND GROWTH}

Scales of Arctic char stocked in 1997 were collected by volunteer anglers from 2000 to 2002 for all three stocked fish of different origin and the naturally bred fish from Lake Annecy. Scales taken from the area between the posterior part of the dorsal fin and the lateral line were cleaned and three scales were photographed with a stereoscopic camera. The age of fish was determined from annual checks. The width of annual growth increments and total scale radius were measured for three scale pictures with a computer program using logarithmic regression between the length of the fish and the size of the scale $(R=0.227 \times L 1.383$; Francis, 1990; Gerdeaux, 1992). If the variance among the three measurements exceeded $20 \%$, additional measurements were made. Mean lengths and standard deviation in successive years of life were calculated for different growth years and for different catch years.

Usually the von Bertalanffy growth function (VBGF), $\mathrm{K}$ and/or Lo parameters are used for comparison of overall growth performance. The VBGF parameters were calculated from backcalculated length data for the 1997 stocking and age at catch data for 1997 and 2001 data using FiSAT II (FAO ICLARM Fish Stock Assessment Tools). Growth comparison of fish based on the single parameter $\mathrm{K}$ or $\mathrm{L} \infty$ can be misleading (Moreau et al., 1985) so it is better to use 
the overall growth performance index $\left(\varnothing^{\prime}\right)$ calculated from VBGF using the equation (Pauly and Munro, 1984) where:

$$
\varnothing^{\prime}=\log K+2 \log L \infty
$$

\section{> FISH DISPERSAL}

Dispersal of the 1997 stocked fish was studied to record overall movement with time. The lake was divided into zones and the volunteer anglers recorded their catch position. This type of data can give only an indication of the dispersion because the fishing effort was not the same everywhere and the quantities of the three different origins were not equal. The raw data were weighted by the quantity of Arctic char caught in each zone and the numbers of stocked fish. No statistics were applied to these data.

\section{> STATISTICAL TESTS}

Growth of different stocks was compared by ANOVA using length at age data and Student's $t$ test pairwise comparison using S Plus.

\section{RESULTS}

\section{> EFFECTIVENESS OF STOCKING}

From the 1997 stocking, the volunteer anglers caught 511 marked and 1650 unmarked Arctic char from 1999 to 2002 (Table I). Scales from 228 unmarked fish were studied to estimate the proportion of naturally born (NB) fish in 1997. The calculated percentage of stocked fish in the volunteer anglers' catch from the 1997 cohort were successively 53, 54, 57 and 46\% for the years 1999 to 2002. Using DDAF data, from 1999 to 2002, 17400 marked Arctic char were estimated to have been caught in Lake Annecy, which was almost $15.8 \%$ of the total stocked in 1997, approximately 6.3 fingerlings stocked for one adult. The effectiveness, i.e., proportion in the catches, was much larger for the LGC fish (24\%) than for the two other types, LAW (8.8\%) and LGW (8.3\%). The results from the 2001 stocking were very similar (Figure 2, Table I).

\section{> FISH GROWTH}

\section{Size at catch}

Anglers started to catch (and release) the Arctic char during the spring of their third year of life, when their mean total length was $21.4 \mathrm{~cm}$ Lt and $19.2 \mathrm{~cm} \mathrm{Lt}$, respectively, for 1997 and 2001 (Figure 3). Length variance was very large, with standard deviation between 2.5 and $4.0 \mathrm{~cm}$ and often a range of $10 \mathrm{~cm}$ or more. The size length in the catches increased during spring of the $3 r d$ year to $26 \mathrm{~cm}$, the minimal legal size. From the autumn of the fourth year the mean length in catches was almost constant, around $31 \mathrm{~cm}$, due to the very high fishing pressure and a life expectancy of less than five years.

\section{Growth}

Among the fish caught during the 3rd year (2000) from the 1997 stocking, LGC showed better growth than all other types, in the 1st, 2nd and 3rd years (ANOVA $p=0.005$ and Student's $t$ test in pairs). At the end of their third year of life most of the stocked fish were recruited to the fishery (Table II). The first to be recruited were the LGC and the last were LGW, which were 
(A) 1997

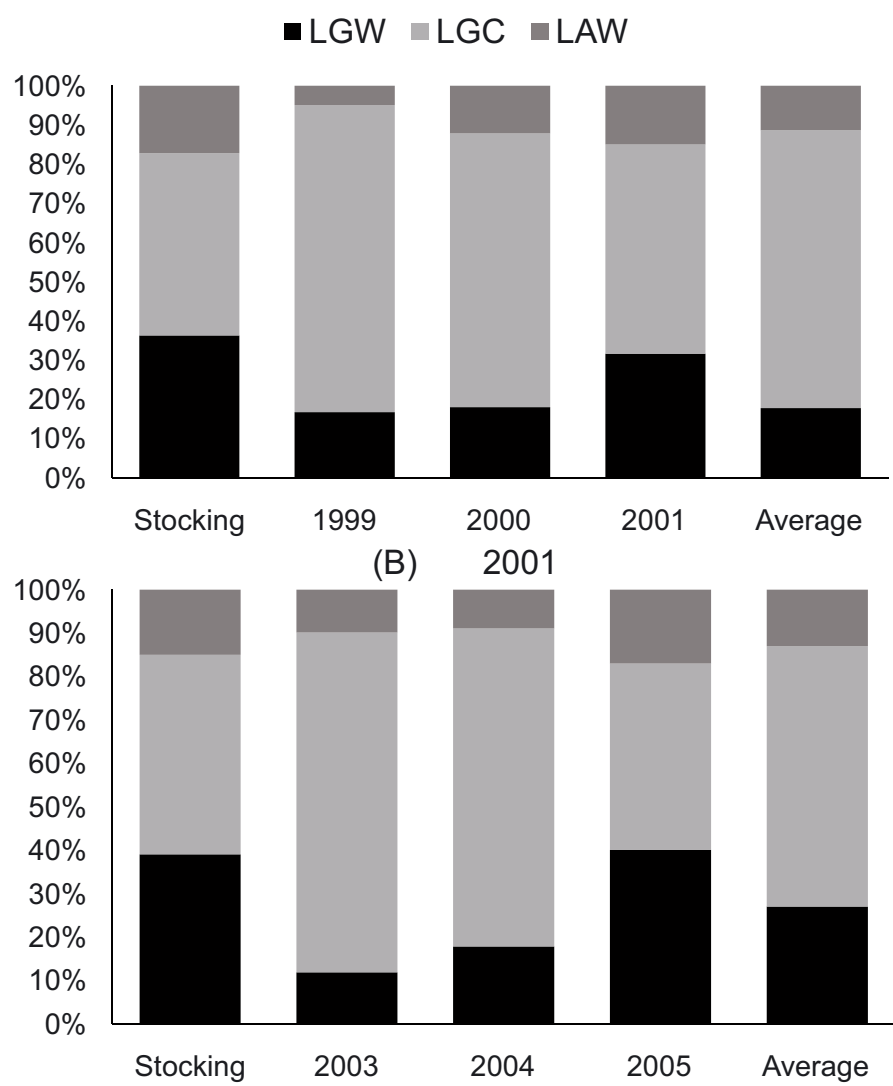

Figure 2

Stocking and recapture percentage of Arctic char in Lake Annecy during the 2nd, 3rd and 4th years after stocking in $A$ (1997) and $B$ (2001).

Figure 2

Alevinage et pourcentage de recapture des ombles chevalier au lac d'Annecy 2 à 4 ans après l'alevinage.

also the fish with the least growth from the stocking. The LGC fish were still the best-growing fish during the 4 rd year with a mean length $2 \mathrm{~cm}$ larger than other fish (ANOVA, $p=0.01$ ). However, statistical analysis showed separation of LGC, while the other three types' growth was statistically similar ( $t$ test in pairs). During the last year, 2002, the number of fish from the 1997 cohort was low in the catches and there was no longer any statistical difference in growth among the different origins of fish $(p=0.07)$. The larger fish, LGC, were almost all caught and only the smaller fish were still in the fishery. The Lee phenomenon is clearly noticeable in these results. The mean size at each age decreased for all three groups of fish through the years 2000 to 2002 . There was not any significant difference in growth between the fish from stocking and the fish from natural reproduction.

The back-calculated length was used to calculate VBGF parameters and the growth performance index ( $\left.\varnothing^{\prime}\right)$ for the 1997 stocking, and the results were very similar; progeny from LGC showed the best growth performance, followed by LAW (Table III). For the 2001 stocking, the scales of the fish were not collected, so length at capture was used to calculate the VBGF and growth performance index, calculating the age from spawning time. The same calculation was also done for the 1997 stocking for comparison. This method may have an important bias because there were no data for the first year of life and as soon as the fish length is above $26 \mathrm{~cm} \mathrm{Lt}$, the fast-growing fish disappeared. However, this bias is for all three stocks, and can be helpful for comparative analysis of different types of stocks. Despite two different techniques, there was not any big difference in the growth performance index of different 

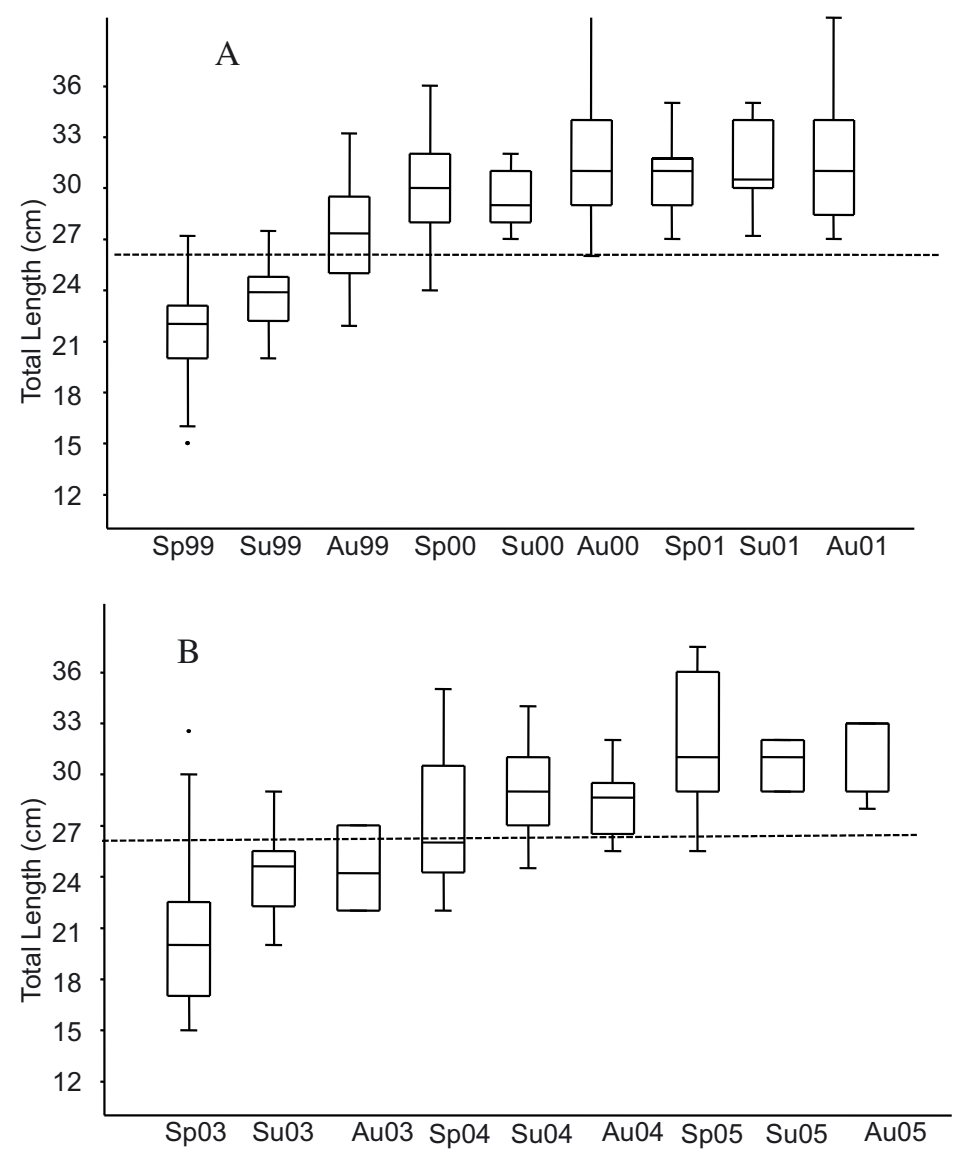

\section{Figure 3}

Seasonal change in size of catch of Lake Geneva captive stock (LGC) stocked in 1997 (A) and 2001 (B) from the third year onwards. Sp (spring), Su (summer) and Au (autumn). Dotted line shows the length of entry into the fisheries $(26 \mathrm{~cm})$.

\section{Figure 3}

Variation saisonnière en taille à la capture des ombles chevalier issus du stock captif originaire du lac Léman (LGC) aleviné en 1997 (A) et 2001 (B) à partir de sa troisième année de vie. Sp (printemps), Su (été) et Au (automne). La ligne pointillée indique la taille minimale de capture $(26 \mathrm{~cm})$.

stocks, with LGC stock having a slightly better growth performance for both the 1997 and 2001 cohorts (Table III).

\section{Dispersal of fish}

The intensity of fishing by the volunteer anglers was not distributed homogeneously in the different zones of the lake and most of the fish were caught by spoonbait fishing in the pelagic zones which are not very precise (Figure 1, Tables IV and V). So, these results could not be very detailed. Two years after stocking, 128 LGC Arctic char were caught throughout the lake, even in the southern part. Few LAW fish were caught after two years and only close to the stocking zone. Few LGW fish were caught in the northern part of the lake. These results were confirmed in 2000, with a higher proportion of LAW and LGW fish in the captures. In 2001 the number of fish from the 1997 cohort decreased a lot and very few were present in the fishery in 2002. 


\section{Table II}

Mean back-calculated total length and standard deviation for Year 1 to Year 5 for naturally produced and stocked Arctic char from different sources during 1997. NB (natural breeding), LAW (descendants of Lake Annecy wild brood stock), LGC (descendants of lake Geneva captive brood stock) and LGW (descendants of lake Geneva wild brood stock).

\section{Tableau II}

Longueur totale rétromesurée et déviation standard de 1 à 5 ans pour les ombles chevalier issus de reproduction naturelle et de différentes origines d'alevinage en 1997. NB (reproduction naturelle), LAW (issus de géniteurs sauvages du lac d'Annecy), LGC (issus d'un stock captif provenant du lac Léman) et LGW (issus de géniteurs sauvages du lac Léman)

\begin{tabular}{|l|c|c|c|c|c|c|c|}
\hline $\begin{array}{l}\text { Catch } \\
\text { Year }\end{array}$ & $\begin{array}{c}\text { Fish } \\
\text { stock }\end{array}$ & $\begin{array}{c}\text { No. of } \\
\text { fish }\end{array}$ & $\begin{array}{c}\text { Tst year (SD) } \\
\text { 2nd year (SD) }\end{array}$ & 3rd year (SD) & 4th year (SD) & 5th year (SD) \\
\hline $\mathbf{2 0 0 0 ~ ( 3 + )}$ & NB & 54 & $110.6( \pm 13.0)$ & $202.8( \pm 20.8)$ & $271.4( \pm 26.5)$ & - & - \\
& LAW & 15 & $114.5( \pm 8.2)$ & $216.4( \pm 13.5)$ & $280.5( \pm 19.3)$ & - & - \\
& LGC & 32 & $121.7( \pm 10.4)$ & $218.9( \pm 15.6)$ & $292.9( \pm 26.3)$ & - & - \\
& LGW & 39 & $108.7( \pm 9.5)$ & $197.8( \pm 17.7)$ & $259.3( \pm 25.9)$ & - & - \\
\hline 2001 (4+) & NB & 63 & $97.8( \pm 11.7)$ & $183.4( \pm 20.1)$ & $254.7( \pm 25.5)$ & $301.5( \pm 27.8)$ & - \\
& LAW & 8 & $101.8( \pm 7.0)$ & $187.7( \pm 7.7)$ & $246.7( \pm 7.5)$ & $291.4( \pm 7.2)$ & - \\
& LGC & 26 & $111.3( \pm 17.3)$ & $200.5( \pm 21.6)$ & $263.0( \pm 24.2)$ & $310.9( \pm 27.5)$ & - \\
& LGW & 20 & $108.7( \pm 29.2)$ & $188.0( \pm 24.2)$ & $243.4( \pm 23.3)$ & $289.0( \pm 27.1)$ & - \\
\hline $\mathbf{2 0 0 2}(\mathbf{5 +})$ & NB & 11 & $94.7( \pm 12.2)$ & $176.7( \pm 17.1)$ & $244.2( \pm 20.9)$ & $295.5( \pm 19.2)$ & $326.7( \pm 26.5)$ \\
& LAW & 7 & $100.5( \pm 7.7)$ & $179.0( \pm 14.2)$ & $241.0( \pm 21.9)$ & $297.3( \pm 22.6)$ & $328.3( \pm 19.3)$ \\
& LGC & 4 & $99.8( \pm 7.8)$ & $177.3( \pm 5.5)$ & $240.0( \pm 6.5)$ & $288.3( \pm 11.7)$ & $315.8( \pm 26.3)$ \\
& LGW & 6 & $98.8( \pm 6.2)$ & $170.4( \pm 13.5)$ & $235.4( \pm 13.1)$ & $289.9( \pm 18.1)$ & $323.4( \pm 25.9)$ \\
\hline
\end{tabular}

\section{Table III}

Von Bertalanffy parameters of naturally produced and stocked Arctic char from different origins in Lake Annecy, stocked during 1997 and 2001. Methods used were (A) back-calculated length at age and (B) observed length at age. $\mathrm{L} \infty$ is asymptotic length, $\mathrm{K}$ is growth curve factor and to is time when length was zero. $\varnothing^{\prime}$ is growth performance index based on L $\infty$ and $\mathrm{K}$.

Tableau III

Paramètres de von Bertalanffy pour les ombles chevalier de différentes origines au lac d'Annecy en 1997 et 2001. Méthodes employées: (A) longueurs rétromesurées, (B) longueur à la capture. Ø' est l'indice de performance de croissance calculé à partir de $L \infty$ et $\mathrm{K}$, paramètres de l'équation de von Bertalanffy.

\begin{tabular}{|l|c|c|c|c|c|c|}
\hline Method & Cohort & Stock & Lo & K & t0 & $\varnothing$ \\
\hline A & 1997 & NB & 44.1 & 0.29 & -0.04 & 2.75 \\
& & LAW & 40.9 & 0.33 & -0.04 & 2.74 \\
& & LGC & 42.0 & 0.34 & -0.05 & 2.77 \\
B & \multirow{4}{*}{1997} & LGW & 41.5 & 0.30 & -0.04 & 2.71 \\
& & LAW & 33.4 & 0.58 & -0.08 & 2.81 \\
& & LGC & 38.5 & 0.44 & -0.06 & 2.82 \\
B & \multirow{2}{*}{2001} & LGW & 37.1 & 0.42 & -0.06 & 2.76 \\
& & LAW & 37.5 & 0.36 & -0.05 & 2.70 \\
& & LGC & 37.5 & 0.45 & -0.06 & 2.80 \\
& & LGW & 35.3 & 0.47 & -0.07 & 2.76 \\
\hline
\end{tabular}

Taking into account the numbers of different types of juveniles stocked and the numbers of Arctic char caught in each zone of the lake by the volunteers (Table IV), the weighted numbers of Arctic char caught by volunteers were 259 LAW, 706 LGC and 261 LGW (Table V). The effectiveness of the LGC progeny was, therefore, three times better than for the LAW and LGW groups. The LGW fish were caught in larger proportion outside the "small lake" where they were stocked. It seems that the movement of the fish is predominantly towards the north of the lake, the direction of the flow in the lake. 


\section{Table IV}

Numbers and zones of 1997 cohort Arctic char caught by anglers during the 2nd, 3rd, 4th and 5th years of stocking. Grey areas show the catches in stocking zones of different stocks. Zones $A$ to $R$ are at the shoreline while Zones $X, Y, Z$ are pelagic zones. See Figure 1. NM is the total number of non-marked fish caught in each zone.

Tableau IV

Effectifs et zones de capture par les pêcheurs amateurs de 1999 à 2002 pour les ombles chevalier nés en 1997. En gris sont figurées les captures dans les zones d'alevinage des différentes origines. NM est le nombre total de poissons non marqués capturés dans chaque zone.

\begin{tabular}{|c|c|c|c|c|c|c|c|c|c|c|c|c|c|c|c|c|}
\hline \multirow[b]{2}{*}{ Zone } & \multicolumn{4}{|c|}{1999} & \multicolumn{4}{|c|}{2000} & \multicolumn{4}{|c|}{2001} & \multicolumn{4}{|c|}{2002} \\
\hline & NB & LAW & LGC & LGW & NB & LAW & LGC & LGW & NB & LAW & LGC & LGW & NB & LAW & LGC & LGW \\
\hline A-B & 28 & & 7 & & 34 & & 3 & & & & 1 & 1 & 20 & 1 & & 1 \\
\hline C & & & 3 & & 15 & 2 & 4 & 1 & & & & & 1 & & & \\
\hline D & 13 & & 7 & 2 & 5 & 1 & 1 & & 3 & & & & 12 & & & 1 \\
\hline E & 12 & & 3 & 2 & 10 & 1 & 6 & & 7 & & 1 & & 18 & & & \\
\hline $\mathbf{F}-\mathbf{G}$ & 2 & & 2 & 1 & 20 & & 6 & 1 & 4 & & 1 & 1 & 17 & & 1 & \\
\hline H & 7 & & 1 & & 7 & & 4 & & & & & & 3 & & & \\
\hline $\mathbf{I}-\mathbf{J}$ & 10 & & 1 & & 12 & & 1 & 2 & 13 & & 4 & 2 & 4 & & & \\
\hline K-L & 16 & & 2 & 1 & 2 & & & & 8 & 1 & & 1 & 6 & & & \\
\hline M-N & 14 & 1 & 1 & & 26 & 1 & 11 & 1 & 4 & & & & 22 & & & 1 \\
\hline 0 & 9 & & 1 & & 9 & & 2 & & 2 & & & & 19 & & 1 & \\
\hline $\mathbf{P}$ & 9 & 1 & 5 & & 26 & 3 & 1 & 1 & 43 & 1 & 1 & 3 & 63 & 5 & & 3 \\
\hline $\mathbf{Q}$ & 15 & & 6 & 7 & 8 & 1 & 4 & & 31 & 1 & 11 & 2 & 29 & 1 & 2 & \\
\hline R & 51 & & 18 & 1 & 26 & 6 & 5 & 1 & 21 & 4 & 2 & 6 & 38 & & & \\
\hline$X$ & 120 & 5 & 60 & 4 & 209 & 10 & 61 & 17 & 81 & 2 & 9 & 4 & 144 & 1 & 1 & \\
\hline $\mathbf{Y}$ & 8 & & 6 & & 27 & & 9 & 4 & 8 & & 2 & 1 & 18 & & & 1 \\
\hline $\mathbf{Z}$ & 16 & & 5 & 1 & 3 & & 1 & & 3 & & & & 21 & & & \\
\hline Total & 330 & 7 & 128 & 19 & 439 & 25 & 119 & 28 & 228 & 9 & 32 & 21 & 435 & 8 & 5 & 7 \\
\hline
\end{tabular}

\section{Table $V$}

Numbers of arctic char of different origin caught by anglers during the 1997 stocking experiment from the different zones (Z) of the Lake Annecy from 1999 to 2002. Data show the actual number of fish caught and weighted values based on stocking numbers and spatial repartition of fishing effort. $Z 1$ and $Z 2$ are near the shoreline while Z3 and Z4 are the pelagic zones. Z1 and Z3 are close to the stocking area while Z2 and Z4 are away from stocking area.

\section{Tableau V}

Nombre d'ombles chevalier de différentes origines capturés par les pêcheurs amateurs après l'alevinage de 1997 dans les différentes zones du lac d'Annecy de 1999 à 2002. Les données indiquent le nombre de poissons capturés et la valeur de ce nombre pondérée par l'effectif aleviné et la répartition de l'effort de pêche. $Z 1$ et $Z 2$ sont des zones littorales alors que $Z 3$ et $Z 4$ sont pélagiques. $Z 1$ et $Z 3$ sont proches de la zone d'alevinage alors que Z2 et Z4 sont des zones éloignées.

\begin{tabular}{|l|c|c|c|c|c|c|c|c|c|c|c|}
\hline \multirow{2}{*}{ Origin } & Number & Raw data of & \multicolumn{10}{|c|}{ Weighted numbers of fish } \\
\cline { 2 - 13 } & & the caught fish & \multicolumn{10}{|c|}{} \\
\hline & & Z1 & Z2 & Z3 & Z4 & Total & Z1 & Z2 & Z3 & Z4 & Total \\
\hline LAW & 18260 & 23 & 8 & 18 & 0 & 49 & 134 & 107 & 18 & 0 & 259 \\
\hline LGC & 51950 & 42 & 89 & 148 & 6 & 285 & 229 & 327 & 113 & 37 & 706 \\
\hline LGW & 40000 & 6 & 37 & 1 & 31 & 75 & 39 & 183 & 5 & 34 & 261 \\
\hline
\end{tabular}




\section{DISCUSSION}

The progeny of captive brood stock from Lake Geneva (LGC) showed a higher growth rate than other stocks for both the 1997 and 2001 experiments. Because of this better growth, LGC entered the fisheries earlier and that increased their capture rate in earlier years. For the 1997 experiment, LGC captured in later years $(2002,5+)$ had a lower growth rate than fish captured in $2000(3+)$. This lesser observed growth of late captured Arctic char is due to the Lee phenomenon (Everhart et al., 1975). Lee's phenomenon is the tendency for back-calculated lengths at a given age in the same cohort of fish to be smaller from the older fish. Ricker (1969) gives one of the explanations of the Lee phenomenon as the presence of faster-growing, but younger-aged individuals of a cohort in earlier samples of the cohort and slower-growing, older-aged individuals in later samples. The fast-growing fish quickly reach the legal size of capture and slower-growing fish enter the fishery later.

The brood stock LGC was reared in an experimental hatchery for 15 years, more than five generations. Hatchery-reared fish are usually faster growing than their wild counterparts of the same cohort, because hatchery managers usually select the brood stock that matures and spawn early (Fleming et al., 2002) and can be different because of the rearing environment (Weber and Fausch, 2003). In hatchery breeding, the brood stock is chosen by hatchery managers rather than by competition as in the wild, so there are also chances of sexual selection (Busack and Currens, 1995) and as a result there may be some behavioural, morphological and physiological differences from the wild population (Weber and Fausch, 2003).

There were large intra-individual variations in the growth of Arctic char, even within the same progeny (Figure 3). Individual differences in growth and food consumption are normal in salmonids (McCarthy et al., 1993; Kahilainen and Lehtonen, 2002). Individual differences in behavioural character, especially dominance, result in difference in growth and size (Björklund et al., 2003). Jobling and Baardvik (1994) found a highly significant positive correlation between food intake and growth of Arctic char and suggested it as the basis of intra-individual growth variations.

The overall growth of naturally produced Arctic char in the 1997 cohort was very similar to that reported earlier by Gerdeaux et al. (1995), for fish caught in 1992 and 1993 . These results showed that growth rates of Arctic char in oligotrophic Lake Annecy were very close to those from the meso-eutrophic Lake Geneva. The overall growth rate of naturally produced Arctic char was not much different from hatchery-released stock and both groups were taken in similar proportions in the catches. The mean effectiveness of the stocked Arctic char was $14.5 \%$ with a large variation of $24 \%, 8.8 \%$ and $8.3 \%$ among LGC, LAW and LGW origins, respectively.

Generally, hatchery-reared fish have lower survival rates and provide lower returns to anglers than wild fish (Heggberget et al., 1992). During the present study, approximately seven juveniles of Arctic char were required to produce one adult in Lake Annecy or roughly 14\% survival, which compares well with other lakes in the region. Champigneulle and Gerdeaux (1995) estimated that 1000 fingerlings are required to produce $40-50 \mathrm{~kg}$ of adult Arctic char fish in Lake Geneva, keeping the average adult weight of $300 \mathrm{~g}$, that is equal to seven juveniles for one adult. Champigneulle et al. (2002) calculated a minimum recapture rate of $10.5 \%$ for Arctic char in Lake Bourget or about 10 juveniles for one adult. For Lake Annecy, Gerdeaux et al. (1995) calculated that a maximum of 13 juveniles were required to produce one adult, presuming that all the Arctic char caught came from stocking. The present studies also showed a clear difference in the effectiveness of the stocks from three different origins with an exceptional effectiveness of LGC stocked fish, probably due to some shift in the life traits of fish because of the hatchery management.

Many researchers have concluded that hatchery-released fish mortality is highest during the first few post-release days (Heggberget et al., 1992; Olla et al., 1998) and have assumed that poor predator avoidance through lack of experience is the cause (Steward and Bjornn, 1990). Cannibalism also plays an important role in regulation of char stocks (Amundsen, 1994; Finstad et al., 2006). In Lake Annecy, the epilimnion is warm in summer and after release, the stocked char swim down fast to the cold hypolimnion where the potential predators are 
principally Arctic char. But population density of fish older than five years, when cannibalism could be highest (Amundsen, 1994), is low and so cannibalism should be low.

Stocked fish were very mobile in Lake Annecy during their first three years and were distributed throughout the lake. LAW stock did not range much beyond their release site in the large lake, and did not cross to the east shore. Some LGW fish moved from the small to the large lake with the water flow. But char were caught in the small lake throughout the year, even in March to June when the water currents come from the south and small tributary streams are flooded with melting snow. A good portion of LGW also moved from the large to the small lake during the three years. In Lake Geneva, only a very small number of tagged fish were able to travel from one end to the other end, about $44 \mathrm{~km}$ in length (Rubin, 1990), but Lake Annecy is only one-third of this length.

The present study has been helpful for understanding some questions regarding the growth and management of Arctic char in Lake Annecy. These types of tagging and stocking experiments with the help of anglers can be very helpful for providing management information at a much lower cost than totally scientific sampling. However, this kind of study requires longterm monitoring and strong motivation of different stakeholders. This study has encouraged the Lake Annecy Anglers Association to rear a captive brood stock in their hatchery at Lake Annecy and increase the stocking size to $8-9 \mathrm{~cm}$.

\section{ACKNOWLEDGEMENTS}

We thank l'Association Annecy Lac Pêche (ALP) and all the volunteer fishermen, without whose help it would have been impossible to collect the data during such a long period. We also thank all the volunteers and staff of INRA Thonon, La Puya Hatchery Annecy and Rive Hatchery Thonon, who helped in marking more than 200000 fingerlings before release.

\section{REFERENCES}

Amundsen P.A., 1994. Piscivory and cannibalism in Arctic charr. J. Fish Biol., 45, 181-189.

Björklund M., Hirovonen H., Seppä T., Peuhkuri N. and Piironen J., 2003. Phenotypic variation in growth trajectories in the Arctic charr Salvelinus alpines. J. Evolution. Biol., 16, 543-550.

Busack C.A. and Currens K.P., 1995. Genetic risks and hazards in hatchery operations. Fundamental concepts and issues. Am. Fish. S. S., 15, 71-80.

Champigneulle A. and Gerdeaux D., 1995. Survey, management and recent rehabilitation of the Artic Char (Salvelinus alpinus) fishery in the French-Swiss Lake Leman. Nord. J. Fresh. Res., 71, 173182.

Champigneulle A., Michoud M. and Brun J.C., 2002. Pacage lacustre de salmonidés (omble chevalier, corégone et truite) dans le lac Léman et le lac du Bourget. In: Gerdeaux D. (ed.), Gestion piscicole des grands plans d'eau, INRA, Paris, 349-421.

Einum S. and Fleming I.A., 2000. Highly fecund mothers sacrifice offspring survival to maximise fitness. Nature, 405, 565-567.

Everhart W.H., Eipper A.W. and Youngs W.D., 1975. Principles of Fishery Science, Cornwell University Press, London, $288 \mathrm{p}$.

Finstad A.G., Ugedal O. and Berg O.K., 2006. Growing large in a low grade environment size dependent foraging gain and niche shifts to cannibalism in Arctic char. Oikos, 112, 73-82.

Fleming I.A., Agustsson T., Finstad B., Johnsson J.I. and Björnsson B.T., 2002. Effects of domestication on growth physiology and endocrinology of Atlantic salmon (Salmo salar). Can. J. Fish. Aquat. Sci., 59, 1323-1330.

Francis R.I.C.C., 1990. Back-calculation of fish length. A critical review. J. Fish. Biol., 36, 883-902.

Gerdeaux D., 1992. Variabilité des mesures scalimétriques chez les corégones du lac d'Annecy. In: Baglinière J.L., Castanet J., Conand F. and Meunier J. (eds.), Tissus durs et âge individuel des vertébrés, Proceedings of Colloque National, 4-6 March 1991, Bondy, ORSTOM-INRA, France, 211-220. 
Gerdeaux D. and Janjua M.Y., 2009. Contribution of obligatory and voluntary fisheries statistics to the knowledge of whitefish population in Lake Annecy (France). Fish. Res., 96, 6-10.

Gerdeaux D., Fillon M.A. and Overmeire V., 1995. Arctic charr, Salvelinus alpinus, of Lake Annecy. Yield growth and parasitism by Eubothrium salvelini. Nord. J. Fresh. Res., 71, 245-251.

Gharrett A.J. and Smoker W.W., 1991. Two generations of hybrids between even- and odd-year pink salmon (Oncorhynchus gorbuscha). A test for outbreeding depression? Can. J. Fish. Aquat. Sci., 48, 1744-1749.

Heggberget T., Staurnes M., Strand R. and Husby J., 1992. Smoltification in salmonids. NINA Forskningsrapport, 31, 3-42.

Jobling M. and Baardvik B.M., 1994. The influence of environmental manipulations on inter- and intraindividual variation in food acquisition and growth performance of Arctic charr, Salvelinus alpines. J. Fish Biol., 44, 1069-1087.

Johnson L., 1980. The Arctic charr, Salvelinus alpines. In: Balon E. (ed.), Charrs - Salmonid Fishes of the Genus Salvelinus, Dr W. Junk, The Hague, 19-98.

Kahilainen K. and Lehtonen H., 2002. Food composition, habitat use and growth of stocked and native Arctic charr, Salvelinus alpinus, in Lake Muddusjarvi, Finland. Fish. Manag. Ecol., 9, 197-204.

Le Roux M., 1908. Le Corégone du lac d'Annecy. Rev. Savoisienne, 1, 116-117.

Le Roux M., 1911. Les poissons du lac d'Annecy et les essais de repeuplement. Rev. Savoisienne, 41, 53-59.

Lorenzen K., 2005. Population dynamics and potential of fisheries stock enhancement. Practical theory for policy analysis and management. Philos. T. Roy. Soc. B., 360, 171-189.

McCarthy I.D., Houliha D.F., Carte C.G. and Mouto K., 1993. Variation in individual consumption rates of fish and its implications for the study of fish nutrition and physiology. P. Nutr. Soc., 52, 427-436.

Moreau J., Belaud A., Daub F. and Nelv A., 1985. A method for rapid growth evaluation in fishes. The case French cyprinid fishes. Hydrobiologia, 120, 225-227.

Olla B., Davis M. and Ryer C., 1998. Understanding how the hatchery environment represses or promotes the development of behavioral survival skills. B. Mar. Sci., 62, 531-550.

Pauly D. and Munro J.L., 1984. Once more on the comparison of growth in fish and invertebrates. Fishbyte, 2, 21.

Ricker W., 1969. Effects of size-selective mortality and sampling bias on estimates of growth, mortality, production, and yield. J. Fish. Res. Board Can., 26, 479-541.

Rubin J., 1990. Biologie de l'omble chevalier (Salvelinus alpinus L.) dans le Léman (Suisse). Ph.D. Thesis, Université de Lausanne, Lausanne, $169 \mathrm{p}$.

Steward C. and Bjornn T., 1990. Supplementation of salmon and steelhead stocks with hatchery fish. A synthesis of published literature. In: W.H. Miles (ed.), Salmon and Steelhead supplementation, Technical Report 901, Bonneville Power Administration, Portland, 1-126.

Weber E.D. and Fausch K.D., 2003. Interactions between hatchery and wild salmonids in streams. Differences in biology and evidence for competition. Can. J. Fish. Aquat. Sci., 60, 1018-1036.

Wessel M.L., Smoker W.W., Fagen R.M. and Joyce J., 2006. Variation of agonistic behavior among juvenile Chinook salmon (Oncorhynchus tshawytscha) of hatchery, hybrid, and wild origin. Can. J. Fish. Aquat. Sci., 63, 438-447.

Wootton R.J., 1994. Ecology of teleost fishes, Chapman and Hall, London, 392 p. 